\title{
CURRÍCULO E AVALIAÇÃO DISCENTE NA EDUCAÇÃO INFANTIL: prática cartográfica dos registros cotidianos
}

\author{
Kezia Rodrigues Nunes \\ Universidade Federal do Espírito Santo - UFES, Brasil \\ Marcos Garcia Neira \\ Universidade de São Paulo - USP, Brasil
}

\begin{abstract}
Resumo
Busca ampliar sentidos de currículo e avaliação nos espaços e tempos da educação infantil. Com centralidade na avaliação discente, justifica-se pela intenção de causar fissuras nas concepções avaliativas diagnósticas de estágio de desenvolvimento e de preparação para o ensino fundamental. Com o investimento metodológico na pesquisa cartográfica, percorre, pelo meio, a produção acadêmica, as políticas públicas educacionais e as práticas pedagógicas de uma instituição da autarquia federal de ensino. A problematização é desenvolvida em uma turma com crianças de três anos. Realiza conexões com a noção de currículos em redes de conhecimentos e com a compreensão de avaliação como prática cartográfica de registros cotidianos. Posiciona-se quanto ao papel social da escola, ao assumir a contribuição da concepção formativa e de instrumentos de avaliação discente que não se pautam na mensuração e padronização para qualificar a intervenção profissional e ampliar as experiências com as crianças. Por fim, problematiza as políticas públicas sistêmicas atuais que valorizam concepções e instrumentos de resultados e não de processos.
\end{abstract}

Palavras-chave: Educação infantil; Currículo; Avaliação discente.

\begin{abstract}
It seeks to broaden meanings of curriculum and assessment in the spaces and times of early childhood education. Central to student evaluation, it is justified by the intention of causing cracks in the diagnostic evaluative conceptions of the stage of development and preparation for elementary school. With the methodological investment in cartographic research, it runs through academic production, educational public policies, and pedagogical practices of an institution of the federal teaching authority. The problematization is carried out in a class with 3-year-old children. It makes connections with the notion of curricula in knowledge networks and with the understanding of evaluation as a cartographic practice of daily records. It takes a position on the social role of the school when it assumes the contribution of the formative conception and instruments of student assessment that are not based on measurement and standardization to qualify professional intervention and expand the experiences with children. Finally, it questions the current systemic public policies that value conceptions and instruments of results and not of processes.
\end{abstract}

Keywords: Early Childhood Education; Curriculum; Student evaluation. 


\section{Uma narrativa inicial ${ }^{1}$}

O debate que articula currículo e avaliação na educação infantil é permeado por diferentes temáticas e tensões, que ora conferem visibilidade aos processos vividos pelos sujeitos, ora mantêm articulação com as instituições. Da Constituição Federal ao Plano Nacional de Educação, em vigor neste ano 2020, são 32 anos de educação infantil, com diferentes movimentos e sujeitos em seus processos de produção curricular e avaliativa. Este trabalho foi ao encontro dessa composição e se manifesta como aposta coletiva de grupos de pesquisa que promovem práticas colaborativas entre a educação básica, a superior e a pósgraduação, para investir em ensino, pesquisa e extensão que qualifiquem nossa atuação docente e nos fortaleçam, rompendo com os permanentes ataques que temos sofrido no tempo atual.

Nos limites deste artigo, voltamo-nos para a avaliação dos sujeitos escolares (avaliação discente) e para os modos como ela tem sido operacionalizada na escola. Ir ao encontro dessa produção escolar cotidiana tem como objetivo ampliar sentidos de currículo e avaliação nos espaçostempos da educação infantil, em atenção às diferentes linguagens das crianças. Problematizamos: o que tem sido articulado a partir da relação entre currículo e avaliação discente na produção acadêmica e nas políticas públicas educacionais? Quais concepções e instrumentos de avaliação descolam esse processo vivido pelas crianças dos julgamentos classificatórios?

Esta pesquisa situa-se no bojo dos estudos pós-críticos da educação, ou seja, de um conjunto de teorias que problematizam a fluidez, a imprecisão e a incerteza do cenário atual e dos estudos do currículo. Com apropriação das produções de Bhabha, Certeau, Deleuze, Derrida, Foucault, Laclau, Mouffe, Hall, Santos, "[...] esse conjunto de teorias inclui os estudos pós-estruturais, pós-coloniais, pós-modernos, pós-fundacionais e pós-marxistas" (LOPES, 2013, p. 10) que, embora importantes e distintos, não serão aqui aprofundados.

De modo mais geral, cabe reconhecer que a apresentação proposta por Silva (1999) nos ajuda a compreender que alguns termos trazem marcas mais gerais das teorizações que compõem os estudos do currículo. São elas: teorias tradicionais (que abordam ensino, aprendizagem, avaliação, metodologia, didática, organização, planejamento, eficiência, objetivos), teorias críticas (que investem em discutir ideologia, poder, classe social, capitalismo, relações sociais de produção, conscientização, emancipação, currículo oculto, resistência) e teorias pós-críticas (que problematizam os conceitos de identidade, alteridade, diferença, subjetividade, significação, discurso, relação saber-poder, representação, cultura, gênero, raça, etnia, sexualidade, multiculturalismo). Esses termos não são exclusivos de uma abordagem e estão em permanente movimento de hibridismo e ampliação (LOPES, 2013), investimento que também nos interessa nessa pesquisa.

Assim, sem negar a forte confluência das demais concepções, bem como o risco dos reducionismos e dicotomias nos limites deste texto, salientamos especialmente as demarcações quanto aos princípios epistemológicos e políticos, no que diz respeito à função social da escola. 
Desse modo, a relação entre currículo e avaliação que nos interessa não está centrada na representação e na regularidade previsível e verificável quanto aos modos de cuidar, educar, brincar e avaliar crianças. Como discutem Gomes et al. (2019), adotar um modelo de currículo e avaliação igualitário para todos/as os sujeitos, reforça os pressupostos que firmaram a ciência moderna, quanto à formação de sujeitos autocentrados, homogêneos e com identidades fixas. Ao se voltar para a realização de diagnósticos dos estágios de desenvolvimento e de preparação para o ensino fundamental, os processos de aprendizagem cotidiana e experiências das crianças são pouco visibilizados.

A relação entre currículo e avaliação que nos interessa considera os sujeitos e suas demandas sociais, culturais, estéticas, éticas, religiosas, dentre outras. Além disso, compreende como currículo não um documento, mas processos de desenvolvimento, ou seja, toda a rede de relações e experiências que compõe as vidas das crianças. Para valorizar essa concepção, o método da pesquisa moveu uma atitude de experimentação, que buscou acompanhar percursos, implicar modos de produção, conectar redes ou rizomas, narrar nossos processos de diferenciação.

Desse modo, nossa opção foi realizar uma cartografia dessa caminhada, tentando problematizar mais do que analisar os percursos empreendidos. Com essa aposta metodológica, que também é política, ética e epistemológica, pelo modo como afirma os limites da pesquisa e do pesquisador em campo, o texto desdobra-se em sessões que fazem conexão com a produção acadêmica, as prescrições curriculares, a abordagem teórica e metodológica, as cenas da pesquisa com o cotidiano e algumas problematizações para ampliar o debate.

\section{Fragmentos do debate da avaliação na educação infantil}

Ao percorrer as produções que abordam a temática avaliação na educação infantil, compreendemos com Rosemberg (2013) que o tema sempre esteve presente, contudo ainda não demarcava um problema social, uma agenda política. A respeito desse aspecto organizacional, Moro e Souza (2014) destacam a coragem como exigência para qualificar tanto o debate quanto as praticaspolíticas dos diferentes agentes nas instituições, sistemas e organizações nacionais e internacionais. É preciso, portanto, considerar que “[...] a avaliação da educação no Brasil tornou-se uma política de Estado a partir das reformas políticas e ações implantadas desde os anos 1990" (ASSIS; AMARAL, 2013, p. 27). Assim, o debate centrado na aprendizagem foi ampliado para as instituições e sistemas (SANTOS; PAULA; STIEG, 2019).

Ainda a esse respeito, Didonet (2012) discute dois aspectos: avaliação na e da educação infantil, diferenciação que se relaciona, respectivamente, com as práticas desenvolvidas com as crianças e com a oferta de ensino realizada pelas instituições ou sistemas. Carvalho e Costa (2013) apresentam três elementos: a avaliação do sistema (federal, estadual, municipal), da escola e da sala de aula. Bauer e Horta Neto (2018) destacam outros três elementos: a avaliação da instituição, dos alunos e dos profissionais de ensino. 
Nunes (2019) considera que essa discussão se desdobra em sete movimentos, centrados: a) nos sistemas, o que inclui os dispositivos do governo (federal, estadual, municipal), as políticas públicas, o monitoramento, a avaliação de larga escala; b) nas instituições, referente à oferta, à qualidade e ao monitoramento do trabalho; c) nas salas de aula, envolvendo a discussão a respeito da qualidade do trabalho, das atividades realizadas, das concepções pedagógicas e avaliativas; d) nos contextos internacionais, em que o movimento é articulado aos sistemas de avaliação, instrumentos e processos; e) nos sujeitos escolares, quando, relacionado com bebês e crianças, aborda a avaliação discente, suas aprendizagens e linguagens; f) nos sujeitos escolares, quando, associado aos profissionais, volta-se para o docente, avaliando seu mérito e formação continuada; g) nos sujeitos escolares, quando se refere aos familiares, aborda estratégias de colaboração.

Na produção acadêmica que discute a avaliação na educação infantil, a complexidade dessa trama ganha maior visibilidade com: os três trabalhos, mapeados por Paz (2005), a respeito da produção presente nas reuniões da Associação Nacional de Pós-Graduação e Pesquisa em Educação (Anped) (1993-2003); os cinco trabalhos identificados por Rosemberg (2013) no periódico Estudos em Avaliação Educacional (1990-2012); os 66 trabalhos localizados por Moro e Souza (2014) na plataforma da Coordenação de Aperfeiçoamento de Pessoal de Nível Superior (Capes), na plataforma Scientific Electronic Library Online (SciELO), no portal de periódicos da Capes e no portal Educ@ (1997 e 2012), somando 7 teses, 35 dissertações e 24 artigos; e os artigos 65 artigos mapeados por Nunes (2019) publicados no Scielo e no portal Educ@ (1999-2018).

No mapeamento realizado por Nunes (2019), 13 trabalhos abordam contextos de avaliação realizada com bebês e crianças. Com maior centralidade nos processos, aprendizagens e linguagens, esses trabalhos não realizam clara identificação das concepções de avaliação discente. Em estudo longitudinal desenvolvido na Inglaterra, Taggart et al. (2011) indicam que estar na escola a partir dos dois anos de idade traz maior benefício para as crianças ao longo da educação infantil e das séries iniciais do ensino fundamental. Os desafios intelectuais, por meio do brincar, bem como o trabalho colaborativo entre os pais e as equipes pedagógicas também contribuem com a ampliação de conhecimentos das crianças. A revisão realizada por Ciasca e Mendes (2009) discute a relevância de um modo de avaliar que esteja articulado à proposta pedagógica, orientada por uma postura docente de registro e reflexão tanto do seu trabalho quanto do desenvolvimento da criança, e também promova atenção às possibilidades de exploração dos pequenos.

Vieira (2018) identifica que, no que se refere à avaliação discente, o debate se circunscreve à avaliação da aprendizagem ou avaliação do desenvolvimento. Do levantamento realizado nas pesquisas em Pós-Graduação em Educação, no período entre 2005 a 2015, a autora seleciona 66 trabalhos (54 dissertações e 12 teses). Nesse mapeamento, constata que, até 2000 , as pesquisas pouco dialogavam com a escola. Também identifica cinco concepções avaliativas: emancipatória, investigativa, mediadora, diagnóstica e formativa. A última é a mais recorrente na educação básica.

Desse mapeamento, Vieira (2018) indica que a concepção diagnóstica (4 trabalhos) é fundamentada em Cipriano Luckesi; a mediadora (6 trabalhos), em diálogo com os estudos 
de Jussara Hoffmann; a investigativa (9 trabalhos), em articulação com Maria Teresa Esteban; a emancipatória (9 trabalhos), embasada em Luiz Carlos Freitas, Ana Saul, Celso Vasconcelos e José Eustaquio Romão; e a formativa (38 trabalhos), baseada na discussão de Phillipe Perrenoud e Charles Hadji. Dentre eles, o trabalho de Hoffmann é o mais utilizado na educação infantil.

Ainda a respeito das práticas curriculares e avaliativas na educação infantil que buscam fissurar as concepções pautadas na mensuração, destacamos os trabalhos de Gomes et al. (2019), Nunes (2019), Nunes et al. (2017), Francelino et al. (2018), Nunes et al. (2018) e Ribeiro et al. (2018), que tomam a creche como espaço e tempo de produção de conhecimento e os sujeitos escolares como importantes atores para pensar coletivamente outros usos dos instrumentos de avaliação.

Ao valorizar essa produção, indicamos, como objeto de investigação, a avaliação discente, ou seja, na educação infantil (DIDONET, 2012), dos alunos (BAUER; HORTA NETO, 2018), da aprendizagem ou desenvolvimento (VIEIRA, 2018), dos sujeitos escolares (NUNES, 2019). Por meio desta revisão de literatura, é importante lembrar que a temática avaliação discente, embora atravesse a educação básica e a educação superior, reserva a cada nível e etapa a sua especificidade de sujeitos, contextos, concepções, instrumentos e processos. Quanto à educação infantil, estamos tratando de bebês e crianças de zero a cinco anos de idade. Afinal, qual concepção de avaliação e instrumentos contribui para dar visibilidade aos seus processos de aprender-ensinar e a qualificar o trabalho docente?

\section{Concepções de avaliação discente nas políticas públicas educacionais}

Ao percorrer os documentos e prescrições curriculares que orientam a educação infantil, da Constituição (1988) ao Plano Nacional de Educação (2014-2024), fomos tateando concepções de currículo e avaliação nesses 32 anos. Seguimos pelo meio, destacando diferentes alianças, como um rizoma, um tipo de raiz que procede por expansão mais do que por definição linear (DELEUZE; GUATTARI, 1995). Nesse percurso, é importante ressaltar que o tema avaliação discente sempre esteve presente, mesmo não demarcando uma agenda política (ROSEMBERG, 2013), aparecendo com mais força no momento atual.

Inicialmente, em um movimento de constituição da educação infantil, há marcas que buscam delimitar esse campo. A Constituição Federal (1988) assegura a educação infantil como direito das crianças de até seis anos e das famílias trabalhadoras urbanas e rurais. $\mathrm{O}$ Estatuto da Criança e do Adolescente (BRASIL, Lei no 8.069/1990) realça crianças e adolescentes como sujeitos prioritários no atendimento aos direitos sociais, considerando a educação como principal direito.

A Lei de Diretrizes e Bases da Educação Nacional (BRASIL; LDB, Lei no 9.394/1996) estabelece a educação infantil como primeira etapa da educação escolar. Define que a educação brasileira é composta por dois níveis: a educação básica e o ensino superior. A educação básica, por sua vez, é dividida em três etapas subsequentes: a educação infantil, o ensino fundamental e o ensino médio. Atualmente, a educação infantil se organiza com 
atendimento em creches (para bebês e crianças com idade entre zero e três anos) e pré-escolas (para crianças com idade entre quatro e cinco anos). Quanto à avaliação discente, a LDB privilegia o acompanhamento da aprendizagem das crianças. Em seu art. 31, discorre: "Na educação infantil a avaliação far-se-á mediante acompanhamento e registro do seu desenvolvimento, sem o objetivo de promoção, mesmo para o acesso ao ensino fundamental" (BRASIL; LDB, 1996).

No âmbito da Câmara de Educação Básica (CEB) do Conselho Nacional de Educação (CNE), ${ }^{2}$ o Parecer CNE/CEB n ${ }^{\circ} 22 / 98$, de 17 de dezembro de 1998, que precede as Diretrizes Curriculares Nacionais para a Educação Infantil (BRASIL; DCNEI, 1999), indica a seguinte proporção para a razão adulto-criança: 1 professor/a para 6 a 8 bebês de 0 a 2 anos; 1 professor/a para cada 15 crianças de 3 anos; e 1 professor/a para cada 20 crianças de 4 a 6 anos (BRASIL; PQNEI, 2006). Essa medida também impacta a qualidade do trabalho docente e o atendimento às crianças. A Emenda Constitucional no 59/2009 (BRASIL; EC, 2009) indica que o ensino será obrigatório entre 4 e 17 anos de idade. A Lei n ${ }^{\circ}$ 12.796/2013 substituiu as modificações realizadas em 2005 e em 2006 e alterou a LDB de 1996, repercutindo na idade do público da pré-escola para 4 e 5 anos, com a implantação do ensino fundamental de 9 anos.

Assim, a cronologia que demarca esse movimento de constituição da educação infantil expressa normas, espaços, sujeitos e atribuições oficiais. Contudo, o movimento faz conexão com um coletivo de forças que pressionaram e contribuíram com o reconhecimento social desses direitos, como as organizações institucionais para a educação e assistência da pequena infância antes desse período, as manifestações das mulheres trabalhadoras, os movimentos populares, os grupos organizados da sociedade civil. Mesmo não tendo sido oficialmente registradas nos documentos citados, as conexões com esse coletivo de forças nos mostram que esses direitos não foram instaurados; foram conquistados.

O que ressoa com esse movimento de constituição? Com as políticas públicas para garantia e manutenção de direitos, seguem em fluxo a cooperação técnica financeira entre os sistemas (municipal, estadual, federal), a valorização profissional do magistério da educação básica, o incentivo à educação por parte do Estado, a ampliação da oferta de vagas em Planos Nacionais de Educação (PNEs). ${ }^{3}$ Para as crianças, houve a conquista do direito de estar na escola e, quanto a isso, podemos comemorar o processo em expansão, tanto na oferta e atendimento na educação infantil quanto na qualificação profissional (SOUSA, 2018).

A geografia desse percurso nos mostra uma demarcação da educação infantil como agenda política (movimento de constituição), bem como um posterior investimento na qualidade institucional (movimento de qualificação). Esse cenário, atravessado por diferentes modos de governo e de compreensão de política pública educacional, é permeado por tensões, disputas, avanços e retrocessos nas concepções que permeiam o trabalho na educação infantil (SOUZA; PÉREZ, 2017). Nesse movimento, o tema avaliação, antes orientado para as crianças, é ampliado para o trabalho pedagógico, a oferta, o serviço, as instituições e o contexto (NUNES, 2019).

Em conexão com o conceito de qualidade, no website do Ministério da Educação, uma lista de prescrições, programas e relatórios, com características de orientação ou fins 
mandatórios, pode ser identificada. Os Parâmetros Básicos de Infraestrutura para Instituições de Educação Infantil (BRASIL; PBIEI, 2006) e os Parâmetros Nacionais de Qualidade para a Educação Infantil (BRASIL; PNQEI, 2006) problematizam o conceito de qualidade institucional. O documento Educação Infantil: Subsídios para Construção de Uma Sistemática de Avaliação (BRASIL; EISSA, 2012) discute sobre a qualidade dos sistemas e da instituição, considerando o acesso, os insumos e os processos. Os documentos Indicadores de Qualidade na Educação Infantil (BRASIL; IQEI, 2009) e Contribuições para a Política Nacional: a Avaliação em Educação Infantil a partir da Avaliação de Contexto (BRASIL; CPNAC, 2015) abordam metodologias de avaliação institucional.

Quanto à avaliação discente e seus instrumentos, as Diretrizes Curriculares Nacionais para a Educação Infantil (BRASIL; DCNEI, 2010) ampliam o foco do acompanhamento do desenvolvimento da criança também para o trabalho pedagógico docente, com uma concepção processual e formativa:

As instituições de educação infantil devem criar procedimentos para acompanhamento do trabalho pedagógico e para avaliação do desenvolvimento das crianças, sem objetivo de seleção, promoção ou classificação, garantindo:

A observação crítica e criativa das atividades, das brincadeiras e interações das crianças no cotidiano;

Utilização de múltiplos registros realizados por adultos e crianças (relatórios, fotografias, desenhos, álbuns etc.);

A continuidade dos processos de aprendizagens por meio da criação de estratégias adequadas aos diferentes momentos de transição vividos pela criança (transição casa/instituição de educação infantil, transições no interior da instituição, transição creche/pré-escola e transição pré-escola/Ensino Fundamental);

Documentação específica que permita às famílias conhecer o trabalho da instituição junto às crianças e os processos de desenvolvimento e aprendizagem da criança na educação infantil; A não retenção das crianças na educação infantil (DCNEI, 2010, p. 29).

Ao considerar a concepção e os instrumentos de avaliação desse documento, compreendemos que os modos de avaliar se afastam da noção de mensuração, classificação, punição ou promoção. De forma complementar, em CPNAC (BRASIL, 2015), há uma defesa pela centralidade dos processos, o que contribui para a adoção de instrumentos de avaliação que confiram visibilidade às experiências vividas (portfólios, relatórios, fotografias, desenhos, álbuns, vídeos).

Assim, rejeitam a avaliação somativa, centrada em desempenho de exames, provas, testes e resultados ao final de um percurso, que podem trazer marcas prejudiciais para a escolarização das crianças. "A avaliação das crianças em creches e pré-escolas é uma responsabilidade fundamental de professores no âmbito da instituição educativa, sendo na circunscrição desse contexto que ela dispõe de significado e valor” (CPNAC, 2015, p. 38). 
A finalidade da educação infantil junto às crianças, também reafirmada nas Diretrizes, Art. $8^{\circ}$ (BRASIL, 2009a, p. 2-3), é garantir o 'acesso a processos de apropriação, renovação e articulação de conhecimentos e aprendizagens de diferentes linguagens, assim como o direito à proteção, à saúde, à liberdade, à confiança, ao respeito, à dignidade, à brincadeira, à convivência e à interação com outras crianças' (CPNAC, 2015).

Essas e outras orientações, que foram construídas num fluxo de coletividade, envolvendo cooperação técnica do MEC com universidades, dirigentes municipais, entidades de pesquisa e grupos sociais, parecem dialogar com as práticas curriculares e avaliativas do cotidiano das escolas.

Contudo, nos mapas dos fluxos que percorremos, identificamos parte de outro efeito que se articula com os dois anteriores, o movimento de controle. O controle, que é sofisticado por estratégias, instrumentos e sistemas de avaliação, revela a heterogeneidade das diferentes concepções em disputa com projetos educacionais distintos. Além disso, parece contribuir com uma concepção que valoriza mais a mensuração, a comparação e os resultados, incidindo sobre uma aposta na avaliação discente da qual buscamos nos afastar.

Como exemplo, a Base Nacional Comum Curricular (BRASIL; BNCC, 2019) não dispõe sobre a especificidade da avaliação discente na educação infantil. Apenas em seu texto introdutório mobiliza uma indicação quanto ao aspecto formativo de processo ou de resultado para a educação básica. Nesse pequeno acréscimo, com a expressão "de resultado", abre uma possibilidade de mensuração dos conhecimentos para qualificar o desempenho dos sujeitos, bebês e crianças, uma vez que indica como necessidade:

- [...] construir e aplicar procedimentos de avaliação formativa de processo ou de resultado que levem em conta os contextos e as condições de aprendizagem, tomando tais registros como referência para melhorar o desempenho da escola, dos professores e dos alunos;

- selecionar, produzir, aplicar e avaliar recursos didáticos e tecnológicos para apoiar o processo de ensinar e aprender (BNCC, 2019, p. 17).

Quais conteúdos serão privilegiados nesses registros? Quais instrumentos serão utilizados para mensurar e qualificar o desempenho das crianças? Qual referência é tomada ao considerar as desigualdades sociais, diferenças histórias, culturais e étnicas que nos atravessam? Tal como discutem Cury et al. (2018), é preciso compreender a quem interessa e favorece determinado projeto de educação com a elaboração desse documento. Ao considerar os processos conturbados de elaboração e aprovação de suas versões (AGUIAR, 2018), bem como o modo como tem sido articulada a interesses de agências internacionais, problematizamos se a base nacional também não é internacional.

Como discute Lopes (2018), na BNCC a qualidade está reduzida à qualidade de ensino, para assimilação de conteúdos, que cumprem expectativas de aprendizagem, que podem ser mensuradas em exames nacionais e internacionais. Nessa equação, "[...] o currículo torna-se cada vez mais dirigido pelas avaliações" (LOPES, 2018, p. 26). Esse campo problemático se 
anuncia porque sempre ressoam sobre a educação infantil perspectivas de avaliação de desempenho realizadas nas demais etapas de ensino ${ }^{4}$ bem como os movimentos internacionais em larga escala. ${ }^{5}$

Nossa preocupação não é inócua. Relaciona-se com dois investimentos brasileiros de avaliação em larga escala para aferir o desenvolvimento das crianças na educação infantil, ou seja, instrumentos que se diferenciam dos orientados pelo documento DCNEI (2010). O primeiro foi realizado em 2010 no Rio de Janeiro com o uso de um instrumento de avaliação do desenvolvimento de crianças, que foi criado nos Estados Unidos em 1997, chamado Ages \& Stages Questionnaires (ASQ) (CARVALHO; COSTA, 2013). O segundo, não efetivado, mas em articulação internacional de planejamento, relaciona-se com a Medición del desarrollo infantil em América Latina: construyendo uma agenda regional (FISZBEIN; GUERRERO; ROJAS, 2016) em que, dentre os proponentes, "[...] participaram membros do movimento Todos Pela Educação e da Fundação Maria Cecilia Souto Vidigal, institutos que vêm se fazendo presentes nas disputas de rumos da educação brasileira" (SOUSA, 2018, p. 71).

O primeiro projeto foi duramente repreendido por fóruns e entidades representativas, que elaboraram manifestos e moção de repúdio contra os métodos avaliativos de crianças de zero a seis anos. Rosemberg (2013, p. 54) discute que essa polêmica, "[...] entre outros aspectos, parece revelar uma preocupação ética com seu uso, além, evidentemente, de críticas à fragilidade de sua precisão e ao viés cultural desses instrumentos". Para Sousa (2018), a segunda proposta revela que permanece a defesa por uma avaliação externa de larga escala do desenvolvimento de crianças na educação infantil e que, além disso, essa articulação mantém acordos internacionais e multilaterais.

A atenção ao movimento de controle também se materializa nas políticas de avaliação educacional mais recentes. Como parte da educação básica, a educação infantil foi incluída na Política Nacional de Avaliação e Exames da Educação Básica (PNAEEB, Decreto n ${ }^{\circ}$ 9.432/2018). Assim como a BNCC (2019), a PNAEEB está atrelada a um modo de composição com a educação básica, centrada em resultados, tal como mencionam os art. $4^{\circ}$ e $5^{\circ}$ :

Art. $4^{\circ}$ Integram a Política Nacional de Avaliação e Exames da Educação Básica:

I - o Sistema de Avaliação da Educação Básica - Saeb;

II - o Exame Nacional para Certificação de Competências de Jovens e Adultos -

Encceja; e

III - o Exame Nacional do Ensino Médio - Enem.

Art. $5^{\circ} \mathrm{O}$ Saeb é um conjunto de instrumentos que permite a produção e a disseminação de evidências, estatísticas, avaliações e estudos a respeito da qualidade das etapas que compõem a educação básica, que são:

I - a Educação Infantil;

II - o Ensino Fundamental; e

III - o Ensino Médio.

De modo complementar a esse decreto, a Portaria $n^{\circ}$ 366/2019 estabelece as diretrizes de realização do Sistema de Avaliação da Educação Básica (Saeb) no ano de 2019. Indica, 
no art. 5, como população-alvo do Saeb 2019: "V - uma amostra de instituições públicas ou conveniadas com o setor público, localizadas em zonas urbanas e rurais que possuam turmas de creche ou pré-escola da etapa da educação infantil, para aplicação exclusiva dos instrumentos previstos nos incisos I, II e III, do art. 11, em caráter de estudo-piloto". Quanto aos instrumentos mencionados, o art. 11 cita:

I - Questionários para Secretarias Estaduais e Municipais de Educação, a serem respondidos pelos titulares da pasta nos Estados e Municípios; II - Questionários para Diretores de Escola, a serem respondidos pelos responsáveis legais das unidades escolares; III - Questionários para Professores das Turmas, para a população alvo dos incisos I, II e V do Art. $5^{\circ}$.

Outra recente portaria (Portaria $n^{\circ} 458$, de 5 de maio de 2020), que institui normas complementares necessárias ao cumprimento da Política Nacional de Avaliação da Educação Básica, estabelece normatizações relativas ao Saeb, sem especificar atributos e dispositivos para a educação infantil. O que decorre dessa opção? Uma liberdade para que os sistemas adotem instrumentos para avaliação de larga escala de competências e habilidades das crianças. A ação de inclusão da educação infantil no Saeb é polêmica, porque não se articula às publicações anteriores, que problematizavam que o conceito de qualidade estava atravessado por um processo de participação e negociação, realizado em um contexto formativo específico, não relacionado com questionários ou relatórios padronizados.

As portarias recentes não assumem claramente, desse modo, as concepções de educação e de avaliação destacadas na LDB (1996), na DCNEI (2010) e no PNE (2014-2024). Novamente, o que decorre dessa opção? Nesses três documentos, há uma orientação para que a criança fosse comparada com ela mesma, e não com um padrão de desenvolvimento externo a ela, a fim de não incorrermos em checagens ou disputas que possam causar estigmatizações e prejuízos para sua formação na primeira infância. O objetivo é o desenvolvimento integral da criança (LDB, 1996). Devemos avaliar as condições de oferta e de acesso dos sistemas e instituições de educação infantil (PNE, 2014-2024).

Compreendemos, então, a qualidade como um conceito polissêmico, socialmente construído, que depende do contexto e é tensionado por diferentes perspectivas (BRASIL, PQNEI, 200). "Qualidade não é algo dado, qualidade se constrói, refletindo-se e discutindo acerca de pontos de vista expressos, negociando; o que requer participação" (BRASIL, CPNAC, 2015, p. 29). A qualidade é participativa, social e contextualmente negociada e transformadora.

A quem pode servir essa concepção de avaliação discente centrada no diagnóstico de estágio de desenvolvimento e de preparação para o ensino fundamental? Entendemos que essa ação não está isolada das demais políticas educacionais. Para Sousa (2018), e concordamos com ela, fica claro que essas medidas procuram atrelar o conhecimento de bases comuns a uma avaliação do desempenho (desde os bebês) com moldes em padrões externos e de larga escala. 
Carvalho e Costa (2013) analisam que se trata de um movimento que avança desde a LDB (1996). Se a concepção de avaliação antes se centrava em uma perspectiva formativa de emancipação social, no momento atual, baseia-se na relação entre gestão e financiamento. "As instâncias oficiais cada vez mais exigem adesão à função da avaliação como controladora para dispor seus recursos e intensificam um viés classificatório, sem focalizar o que compete a ela" (CARVALHO; COSTA, 2013, p. 181). Os autores indicam a necessidade de um processo de avaliação e reflexão que articule os sistemas, as escolas e as salas de aula (CARVALHO; COSTA, 2013, p. 187):

É necessário um processo de avaliação e reflexão sobre a escola, em todos os seus meandros. Como afirma Freitas (2007, p. 980), 'os três níveis de avaliação (sistema, escola e sala de aula) devem estar trabalhando articuladamente e segundo suas áreas de abrangência', o que exige disponibilidade de tempo não somente no início do ano ou de forma rápida em encontros trimestrais, mas que sejam contínuas e longitudinais porque há várias questões sobre as quais a escola precisa se debruçar. Entre elas, destacam-se a forma de avaliação, de agrupamento, as condições de trabalho, o número de crianças em cada sala, as faltas de alunos e professores, assim como vários outros pontos que devem ser levados em conta para que haja uma melhor compreensão da escola e para que o coletivo de profissionais possa encontrar meios para minimizar ou superar as dificuldades.

As políticas públicas caminham ao encontro de um movimento que vem se constituído desde a década de 1990, marcado pela avaliação externa, pela expansão do ensino fundamental e também da educação infantil, pela municipalização e descentralização, entre outros aspectos que caracterizam a educação brasileira. A nossa defesa é por uma educação pública, gratuita, de qualidade, que tome como centralidade a criança ( sua condição no tempo presente), os profissionais (o permanente investimento na valorização e formação do magistério e demais trabalhadores, bem como nas condições de trabalho) e o contexto (da qualidade da instituição). Ao considerar esses movimentos multiformes e polissêmicos, que aqui tratamos como constituição, qualificação e controle, problematizamos: qual a ressonância das concepções teóricas e políticas públicas de avaliação discente nas práticas pedagógicas docentes?

\section{Entre currículos e avaliações: prática cartográfica de registros cotidianos}

No que diz respeito a currículo, nossa compreensão não se reduz à prescrição curricular ou à elaboração de documentos. Reconhecemos a impossibilidade de abordar esse conceito como algo definido, fechado quanto à terminologia ou à função, uma vez que se trata de um campo que envolve disputas, tensões e permanentes ampliações. 
Com Sacristán (2000), é possível compreender o currículo como um sistema, em que estão em articulação permanente seis contextos de produção, que ele chama de subjetivações do currículo. São eles: currículo prescrito, currículo apresentado aos professores, currículo modelado pelos professores, currículo em ação, currículo realizado e currículo avaliado. Eles mantêm relações recíprocas com outros dois condicionantes: os escolares e os contextos (econômico, político, social, cultural e administrativo). Esses determinantes expressam ação reguladora tanto nas práticas quanto nos sujeitos escolares. Ao perceber essa rede de operações que influencia a prática pedagógica dos professores/as e demais servidores/as da instituição, é possível compreender o currículo como um processo de construção social (SACRISTÁN, 2000), resultado das diversas operações às quais é submetido.

Esse processo mantém composição com os sistemas (os contextos federais, estaduais, municipais) e com as outras instituições (as escolas e a comunidade escolar), mas se expande para além deles, porque se conecta como uma rede a tudo que se produz dentro e fora da escola e demais instituições, não se restringindo ao que se passa nelas. Assim, vamos ao encontro dessa concepção que nos interessa destacar e ampliar. Compreendemos que o currículo se situa em meio a movimentos rizomáticos que acontecem por dentro uns dos outros, uma vez que ambos se proliferam e ramificam em linhas que se cruzam, sempre pelo meio. Assim, a noção de níveis ou de objetivações curriculares é ampliada com a imagem de rizoma, um tipo de raiz que não cresce de modo ascendente, como uma árvore, mas é conhecida pelo modo como se expande. Como afirmam Deleuze e Guattari (1996, p. 37), "[...] um rizoma não começa nem conclui, ele se encontra sempre no meio, entre as coisas, inter-ser, intermezzo"”.

Nossa aposta está na compreensão de currículo como redes de conhecimentos, saberes, fazeres, poderes e afecções. Um dispositivo com linhas de diferentes segmentaridades e fluidez. Envolve as complexas conexões com as prescrições instituídas, as dimensões vividas cotidianamente nos seus diferentes espaços-tempos de produção, a reinvenção a partir da confluência de múltiplas demandas da vida cotidiana, os saberes-fazeres das crianças e dos adultos, o aparato didático-pedagógico mobilizado e produzido, as opções teóricometodológicas, as propostas e projetos escolares de diferentes níveis, os improvisos, as contradições, as documentações, as invenções, as afecções, as conversações, as narrativasimagens, enfim, as múltiplas redes de sentidos-produções (NUNES; FERRAÇO, 2018).

Ainda com Deleuze e Guattari (1996), compreendemos que esses diferentes fluxos contribuem para a emergência de novas concepções de currículo e de avaliação na educação infantil, que estão sendo gestadas cotidianamente e que precisam ganhar visibilidade. Atravessados pelo que podemos considerar como currículo real (SACRISTÁN, 2000), currículos em redes (ALVES, 2008), currículo realizado (FERRAÇO, 2008) e currículo praticado (OLIVEIRA, 2008), assumimos o que foi produzido com os praticantes escolares como pistas fundamentais para as negociações efetivadas e pela diferença que permeia suas redes de conhecimentos (NUNES; FERRAÇO, 2018).

Tal como as conexões que compõem os currículos, compreendemos que as práticas avaliativas que tratam das crianças na educação infantil também devem considerar muito mais esses elementos do que as categorizações objetivas e superficiais expressas em 
formulários ou relatórios descritivos das aprendizagens das crianças, documentos que pouco dialogam com as expectativas das famílias ou com a intensidade vivida com as elas e com as professoras na escola.

Em diálogo com um currículo como redes de conhecimentos, investimos na avaliação como prática cartográfica de registros cotidianos (NUNES, 2019). Essa concepção envolve os processos (do que é feito, como é feito, onde se faz, como reunimos ou fabulamos narrativas com os registros). Articula-se com as concepções da avaliação da aprendizagem, como a avaliação diagnóstica (quem é e o que sabe), avaliação somativa (da aprendizagem), avaliação formativa (para aprendizagem) para rasurar seus contornos, conceitos e funções. Isso se dá porque o maior interesse consiste em realizar registros dos processos vividos, que orientam outras intervenções docentes no encontro com as crianças e conferem visibilidade às diferentes experiências escolares. Endossamos a defesa de que o parâmetro, segundo o qual se deve estimar a qualidade de atendimento na educação infantil, é a avaliação dos sistemas e não a avaliação da aprendizagem das crianças (BHERING; ABUCHAIM, 2014).

Os registros são feitos pelas crianças, pelas professoras e, quando solicitados, pelas famílias. No entanto, quem decide e seleciona o conteúdo (fotos, vídeos, atividades), o formato que pode ser compartilhado (portfólios, cartazes, mostras, produção cinematográfica) e o objetivo da mensagem (realizar diagnóstico, categorização, fabulação, visibilidade ao vivido) são as professoras. Nossa intenção é fazer conexão com esses movimentos entre o vivido e o registrado, abordando tanto o que tem sido produzido quanto suas possibilidades de ampliação de redes de sentidos de avaliação discente vividos no encontro com as crianças.

Quanto ao investimento metodológico, a pesquisa cartográfica conduziu um modo de estar na escola. Para Kastrup (2007), a atitude problematizada por Deleuze e Guattari (1996) envolve diferentes posturas do pesquisador a respeito do modo como ele dispensa sua atenção em campo e indica, como opção, a concentração sem focalização. Refere-se a uma abertura aos encontros inesperados, à dimensão do acontecimento, às experiências que aparentemente não se relacionam com o tema da pesquisa, mas que tratam da dimensão da processualidade em curso. Considera ainda que, no trabalho com a cartografia, a atenção reúne diferentes variações, que não mantêm uma ordenação ou hierarquização entre si: o rastreio, o toque, o pouso e o reconhecimento atento. Nesta pesquisa, motivou a redução do foco, como um zoom em determinados movimentos e temáticas.

O movimento de rastreio propõe uma abertura em campo com ampla focalização. Assim nos movemos para identificar qual seria a instituição colaboradora, dentre as duas parceiras em projetos de pesquisa, extensão e ensino anteriores. Ao considerar as condições objetivas de realização da pesquisa, em razão de uma greve dos servidores municipais, um gesto de toque foi realizado para configurar um novo território, delimitando esse mapa e ampliando a intensidade do percurso com a definição de um CEI, que é da autarquia federal de ensino. Após permanentes reelaborações nos primeiros meses de trabalho em duas turmas, um gesto de pouso definiu como público principal o Grupo 3, com crianças de três anos de idade, em que participaram as crianças e duas professoras (uma regente do quadro institucional e outra assistente voluntária, que compartilhou com a professora o trabalho nesse ano letivo). Como 
procedimento para produção de dados, foram utilizados diário de campo, registros fotográficos e fílmicos, conversas, documentos escolares e produções das crianças.

Quanto ao quadro de profissionais, cabe destacar que garantir a razão professor-aluno tem sido um dos desafios institucionais motivados por diferentes questões: a aposentadoria de parte dos/as professores/as e assistentes; o recente decreto ${ }^{6}$ que extinguiu o cargo de assistente na rede federal de ensino, o que limitava a nomeação de servidoras que foram aprovadas em concurso público e justificava a ausência de contratação de servidoras em regime temporário de trabalho; a redução do orçamento nas universidades e demais instituições educacionais públicas, resultado de medidas como a Emenda Constitucional $\mathrm{n}^{\mathbf{o}}$ 95/2016, que restringe o investimento com cortes de pessoal. Esses elementos geravam uma permanente negociação institucional com professores/as voluntários/as e estagiários/as de diferentes cursos para compor a equipe.

Para o Grupo 3, por exemplo, não havia assistente do quadro efetivo de funcionários para trabalhar com a professora regente. Sua equipe foi sendo alterada ao longo do ano 2018 , ora com uma professora assistente, ora com duas, ora com uma estagiária (de Pedagogia, de Artes, de Música), ora sem ninguém. Essa situação gerava muitos conflitos com a equipe pedagógica, com as crianças e com as famílias, interferindo na saúde da docente pela exigência que lhe recaía em administrar essa equipe volátil. Por vezes, ela permaneceu sozinha com as suas 20 crianças de três anos de idade. Cenas das tensões vividas no pouso no cotidiano escolar.

\section{A avaliação como prática cartográfica de registros cotidianos e seus instrumentos}

Os registros do Projeto Político-Pedagógico (PPP) indicam que, em 1976, houve um primeiro atendimento na instituição; em 1997, a unidade foi vinculada ao Centro de Educação da Universidade; em 2012, por meio da Resolução $n^{\circ}$. 48/2012, essa unidade de creche universitária torna-se Centro de Educação Infantil universitário institucionalizado, o que possibilitou mudança no quadro de servidores, como a realização de concurso público. Em relação ao público atendido, a configuração se realiza por vínculo em cada um dos segmentos: filhos de docentes (21\%), filhos de servidores técnico-administrativos em educação (19\%), filhos de alunos da universidade (27\%) e filhos de membros da comunidade externa $(33 \%)$.

Nos fluxos que o atravessam, uma grupalidade heterogênea se apresenta nas discussões no PPP, ao indicar investimentos teórico-metodológicos nas concepções críticas e póscríticas: a opção metodológica por projetos, a concepção de currículo como agenciamento maquínico, a orientação com base na sociologia da infância e a gestão democrática e participativa. Quanto à avaliação discente, não há registros de concepções ou instrumentos do grupo. No entanto, indicam articulação com as orientações da DCNEI (BRASIL, 2010) e com o Parecer CEB no 17/2010, que trata das normas de funcionamento das unidades de educação infantil ligadas à Administração Pública Federal direta, para o seguinte 
compromisso docente assumido no PPP (2017, p. 31-32): “[...] escreva o processo de acompanhamento e registro do desenvolvimento integral da criança, tomando como referência o projeto pedagógico da escola, cujo sistema de avaliação não pode ter a finalidade de promoção".

Para além do que está registrado nas prescrições da instituição, o movimento de reconhecimento atento (KASTRUP, 2007) nos movia a aprender a realizar uma performance em campo, a acompanhar os processos vividos, descolando-se da recognição, ou seja, de uma intenção em reconhecer e afirmar o que está dado, descrevendo algo. Essas variações estão ligadas ao modo como o pesquisador expande ou concentra-se em determinada temática. Nesse caso, relaciona-se com a atenção às diferentes demandas curriculares com os sujeitos da instituição, o que nos motivou a participar da acolhida, lanches, visitas pedagógicas, ensaios, contação de histórias, atividades, brincadeiras, exposições dos seus trabalhos, planejamentos docentes, dentre outros. Desse modo, a escrita não narra apenas o que vimos, mas o que escutamos, sentimos, tocamos, planejamos, o que irrompeu no cotidiano escolar e contribuiu para a elaboração de um investimento na temática avaliação discente na educação infantil.

Ao acompanhar, planejar, avaliar e estudar com o Grupo 3, fomos conectados por motivações e preocupações, com diferentes focalizações quanto à sua intensidade. Uma delas estava associada a pensar a criança e sua relação com a casa, o bairro e o planeta. Uma outra estava vinculada a uma polêmica, levantada com mães e pais, sobre o modo como consideravam os filhos como bebês. As permanentes orientações docentes com as crianças mostravam a importância do cuidado de si e do outro e motivaram a adoção de dois peixes para serem cuidados pelas crianças em suas casas, tal como expressa a narrativa da professora:

- A temática 'Eu no mundo' tem sido utilizada de modo recorrente por mim. Ano passado, o projeto foi 'Eu no mundo: criarteiros em movimento', com releituras das obras artísticas naif da capixaba Ângela Gomes. Neste ano, além de problematizar a criança e seu entorno, a expressão 'Não sou mais bebê' estava muito presente nas suas falas desde a chegada na escola. Se eles não são mais bebês, podem cuidar do amigo, porque 'amigo cuida do amigo', outra fala muito presente em nosso trabalho. Com mais autonomia, também podem cuidar de outro ser vivo. Por isso, trouxemos o peixe para circular por dois dias nas casas deles, com comidinha e tudo. Até os nomes escolhemos coletivamente. A intenção era que as famílias fizessem um registro desse periodo, com narrativas e fotos, além de deixar uma mensagem para os/as filhos/as. Cada trecho de emocionar! (PROFESSORA DO GRUPO 3).

De modo amplo, uma das intenções era conectar relações para além da sala de aula na escola, preocupados em romper com a esterilidade das práticas no chão de cimento. Esse elemento motivou-nos a tomar o pátio como potencializador de experiências para criar condições de desemparedamento da infância. Contamos com inspiração nas experiências divulgadas pelos projetos do Instituto Alana, como o Território do Brincar, Projeto Criança 
e Natureza, o movimento internacional de Revitalização dos Pátios Escolares e os Guias das brincadeiras nos pátios escolares $(2017,2018)$. Esse mapeamento fazia composição com os desafios registrados no Projeto Político-Pedagógico (PPP) a respeito de outros usos para os espaços externos bem como de estratégias de revitalização.

A relevância social consistia no permanente estudo e problematização com as crianças e suas famílias dos impactos de nossa intervenção na escolha cotidiana de ações sustentáveis para a preservação do planeta, no uso consciente dos recursos naturais e suas fontes e de nossa responsabilidade pelos bens naturais. Do planeta para o nosso pátio, aumentando o zoom da intensidade vivida, desdobraram-se dessa leitura a vivência de atividades com materiais naturais colhidos no entorno (gravetos, sementes, folhas, pedras, argila) nas composições e brincadeiras em sala, a criação e manutenção de um jardim, o renovo e uso do pátio com lamas e percursos com água.

A intenção dessa narrativa é evidenciar as redes de relações e ações complexas que compõem as práticas curriculares, que não se determinam por meio de um único dispositivo, como as prescrições curriculares, tal como nos lembra Ferraço (2008), ao nos dizer que, a despeito de nossa pretensão em engessar sentidos ou modos de pensar, os movimentos das redes cotidianas produzem deslizamentos impossíveis de serem previstos ou controlados.

Essa rede contribuiu para eleição de um trabalho com elementos mais naturais, como brincadeiras no quintal, em que os quatro elementos da natureza (terra, água, ar, fogo) foram tomados como temáticas para pensar a relação das crianças no mundo e as possibilidades de ampliar seus modos de brincar. A partir dessa contextualização do trabalho da instituição e da sala de aula, voltamo-nos para alguns instrumentos de avaliação utilizados pelas professoras em composição com esta pesquisa. Lembramos que todos eles já são utilizados pelas professoras dessa escola, buscamos potencializar o conteúdo e os modos de uso.

$O$ primeiro instrumento é o caderno da professora, que incluía os planejamentos semanais, a indicação das atividades e uma narrativa dos processos vividos. Assim, é importante ressaltar que a concepção de projetos da professora, que está articulada ao PPP da instituição, não mantinha vínculo com uma ideia de projeto como completude, como determinação do futuro ou com ênfase na aprendizagem ativa das crianças. O que caracteriza esse projeto é a negociação no coletivo, que segue a indeterminação de todas as suas ações por uma aposta na composição processual com os sujeitos.

No primeiro semestre, a partir do tema água, passamos ao tema terra. O registro docente movia o permanente movimento de mapear conhecimentos (associados aos contextos do PPP da escola, às demandas da sala de aula, ao uso do pátio, às possibilidades em casa, às demandas do planeta), vivenciar experiências com diferentes linguagens (brincar, pintar, rolar, escrever, desenhar, manusear os elementos não estruturados da natureza) e ampliar possibilidades de intervenção (inventar histórias coletivas, cuidar do peixe que foi para casa, formar e preservar um jardim).

Desse modo, os registros vinculam-se, ainda, às orientações a respeito da avaliação discente na educação infantil, quanto à sua concepção processual e formativa, centrada no acompanhamento do trabalho pedagógico, por meio de "[...] múltiplos registros realizados por adultos e crianças (relatórios, fotografias, desenhos, álbuns etc.)" (BRASIL; DCNEI, 
2010, p. 29). Para as professoras, a prática de registros consiste em um importante instrumento para permanente reelaboração do trabalho com a riqueza de fontes e processos vividos com os sujeitos escolares. A contribuição das práticas de registro bem fundamentados para orientação do trabalho pedagógico também é discutida por Muller e Neira (2018).

$O$ segundo instrumento é o relatório, que mobiliza uma narrativa para contextualizar o trabalho realizado semestralmente. Como discutem Ciasca e Mendes (2009), consiste em uma referência para registro dos processos de conhecimento individuais e coletivos das crianças, bem como para registro e avaliação do trabalho docente. Essa é uma estratégia para conferir visibilidade aos processos vividos, que se expandem e se contraem no movimento de racionalizar nosso encontro com os corpos (dos sujeitos e dos objetos) e com os incorporais (paixões, afecções e sensações), produzindo uma rede de sentidos nesse contexto. Um investimento na composição entre currículo, avaliação e afecção, que busca se afastar da descrição.

Foto 1 - Relatórios descritivos de avaliação discente

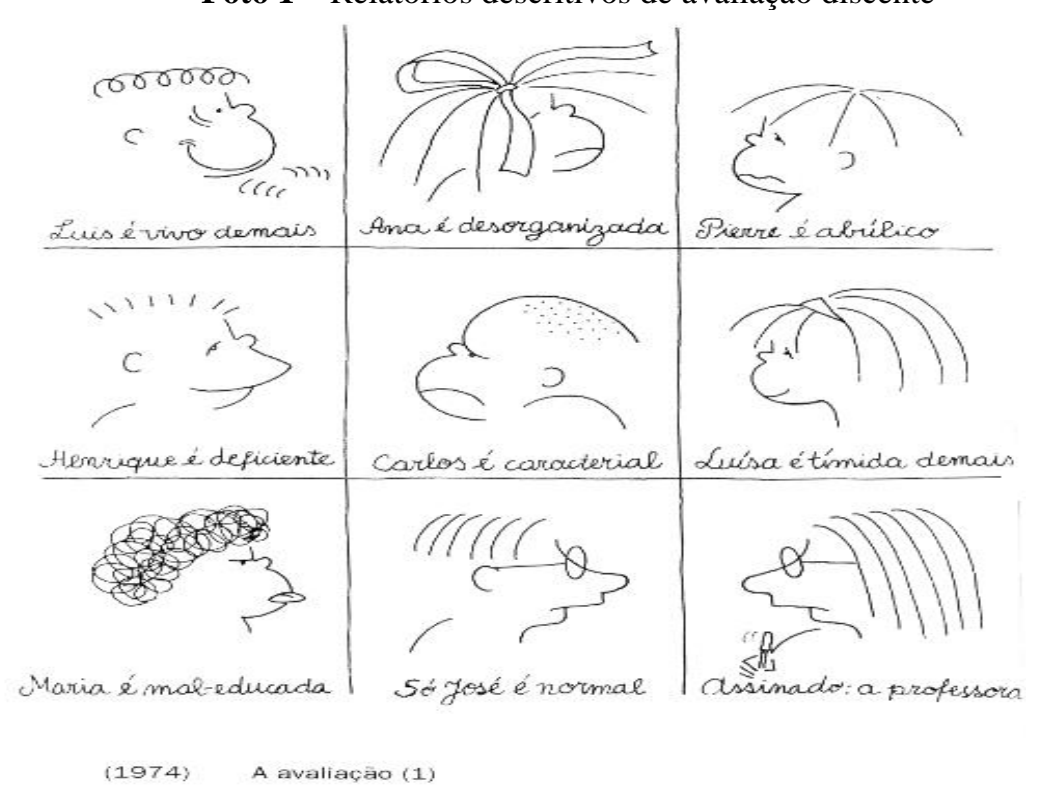

Fonte: Tonucci (1974).

Trata-se de uma seleção de parte dos encontros vividos e registrados pela professora. Nesse caso, o registro não descreve a criança e não se relaciona apenas com ela, mas revela o que afetou a professora (e as famílias) e foi capturado como mais expressivo. Na charge de Tonucci (1974), Foto 1, a professora descreve uma característica para cada estudante e indica que apenas uma é considerada normal, a que se assemelha a ela. A concepção de relatório da charge, tão presente em muitas práticas, fala mais sobre a professora do que sobre a criança.

Em nossa pesquisa, problematizamos a intenção de fugir dos registros que classificassem as crianças em etapas de desenvolvimento cognitivo ou que realizassem quaisquer comparações entre elas que pudessem desqualificá-las segundo o que se espera para essa fase 
ou idade. Desse modo, foi elaborado, no primeiro semestre, um relatório das atividades, e não das características das crianças:

Essa é a história do Grupo 3. Uma turma com crianças muito sapecas que tem vivido uma aventura coletiva! $E$ esse foi o maior desafio de suas professoras, porque, quando o ano letivo começou, eles ainda não sabiam que eram o Grupo 3. Eles foram aprendendo... a cuidar de si e dos amigos, a ter mais autonomia, a fazer tarefas simples, tais como: calçar os sapatos, escovar os dentes, buscar a sua comida, entregar os pratos. Também começaram a aprender as letras do seu nome e as dos colegas, as formas geométricas, as cores, os tamanhos, as espessuras, os números e as quantidades. Foram experimentando a negociação, tanto da atenção das professoras quanto dos brinquedos com os/as colegas. Aprender também é experimentar! (TRECHO DO RELATÓRIO DO PRIMEIRO SEMESTRE, 2018).

Ao reelaborar o seu uso, ao fabular uma história a respeito do projeto realizado, destacamos suas interações com as temáticas que potencializaram modos de conhecer e brincar. Assumimos, assim, a sua dimensão de fabulação e nos colocamos em movimento com os rastros de memória da intensidade dos encontros com as crianças. No segundo semestre, o relatório foi individual e buscou valorizar as experiências ampliadas ao longo do ano. Esse investimento dialoga com a problematização de Gomes et al. (2019, p. 340), em que a avalição discente é pensada como acompanhamento e investigação dos processos aprendentes e não como monitoramento e classificação, articulada apenas ao cumprimento de uma prescrição curricular:

Avaliação da aprendizagem e o próprio ato de aprender escapam do controle linear, pois, como gosta de afirmar Deleuze (2007), 'o pensamento é da ordem do impensado', então, como prever? Como estabelecer critérios que desconsideram os 'múltiplos devires' (DELEUZE; GUATTARI, 1995) que atravessam o plano de imanência? Como, então, podemos determinar o que alguém vai aprender se a aprendizagem está vinculada aos processos de afetação? É possível sistematizar o que se espera que a criança alcance para avançar para a próxima etapa?

O terceiro instrumento é o portfólio individual, que, nessa turma, foi organizado em fichários. Também conhecido como documento ou dossiê, reuniu um conjunto de atividades, fotos e materiais para dar visibilidade às experiências individuais e coletivas vividas na escola. Essas produções procuram agrupar com mais expressividade o que se espera da escolarização, no esforço de abordar como conteúdo: iniciativas de alfabetização, escrita dos nomes das crianças, identificação dos primeiros algarismos arábicos, desenhos livres, ilustrações que buscam retratar alguma experiência, atividades realizadas com as famílias, fotos de diferentes episódios contextualizados pelo projeto temático. A opção da professora foi realizar uma seleção cronológica das atividades, para compreender as mudanças 
desenvolvidas ao longo do ano. Quanto aos registros das crianças, tomamos suas narrativas e desenhos a partir dos processos vividos no cotidiano escolar.

- Eu gostei de escorregar (na lona com água). O meu pai me joga lá no alto na piscina e eu caio (MENINA).

- Eu gostei da aventura na floresta (MENINO).

- Eu gostei, mas eu fiquei com medo (MENINA).

- Eu fiquei com medo também do desafio (MENINO).

- Tinha um leão, eu gostei de pendurar na árvore, e tinha a cobra (MENINO).

(CRIANÇAS do Grupo 3, trecho do diário de campo).

De acordo com as prescrições curriculares, é importante elaborar uma “[...] documentação específica que permita às famílias conhecer o trabalho da instituição junto às crianças e os processos de desenvolvimento e aprendizagem da criança na educação infantil" (BRASIL; DCNEI, 2010, p. 19). Ciasca e Mendes (2009, p. 302) discutem que esse instrumento não deve apenas reunir trabalhos, de modo burocrático, mas expressar "[...] avanços conceituais, novas formas de pensar e de fazer alusão ao progresso do estudante".

Contudo, o registro é sempre parcial quanto à intensidade vivida e diminui com os diferentes modos de expressão. Uma coisa é escorregar, outra é falar sobre o prazer/medo/alegria em escorregar, outra é ter sua narrativa registrada neste texto, que não expressa a intensidade da experiência vivida no pátio ou da conversa realizada a seu respeito. São ações de natureza diferente. Assim, é sempre um esforço da parcialidade desse investimento em relação ao que é registrado no corpo: o medo, o prazer, a alegria, a repulsa, as estratégias para ampliar velocidade, os deslocamentos (de frente, de barriga, de bumbum).

Nossa problematização foi robustecida quando tomamos o uso dos desenhos das crianças como registro e sistematização das experiências mais significativas. Embora houvesse uma orientação e mediação quanto ao contexto, problematizando com as crianças momentos que poderiam ser privilegiados, como os que fizeram parte de suas narrativas ("a caça ao tesouro", "o mergulho no tuboágua"), as crianças desenhavam o que queriam! É importante destacar que isso não causava desconforto para as docentes. Nessa prática, tão comum na educação infantil e no ensino fundamental, a postura das professoras não era coercitiva com relação ao uso dos desenhos como estratégia para registro do vivido.

A experiência do desenho, muitas vezes, é de criação, de fruição, de encantamento com a vida. Assim, quando compreendemos que a narrativa e a experiência vividas nem sempre manifestam vínculo com a experiência de desenhar, ou seja, uma ausência de reciprocidade entre o vivido e o registrado, reconhecemos que as crianças também usam os desenhos para fabular, inventar, delirar, riscar, como registrado na Foto 2. 
Foto 2 - Composição para os portfólios individuais: entre o cuidado com o peixe e a liberdade da criação
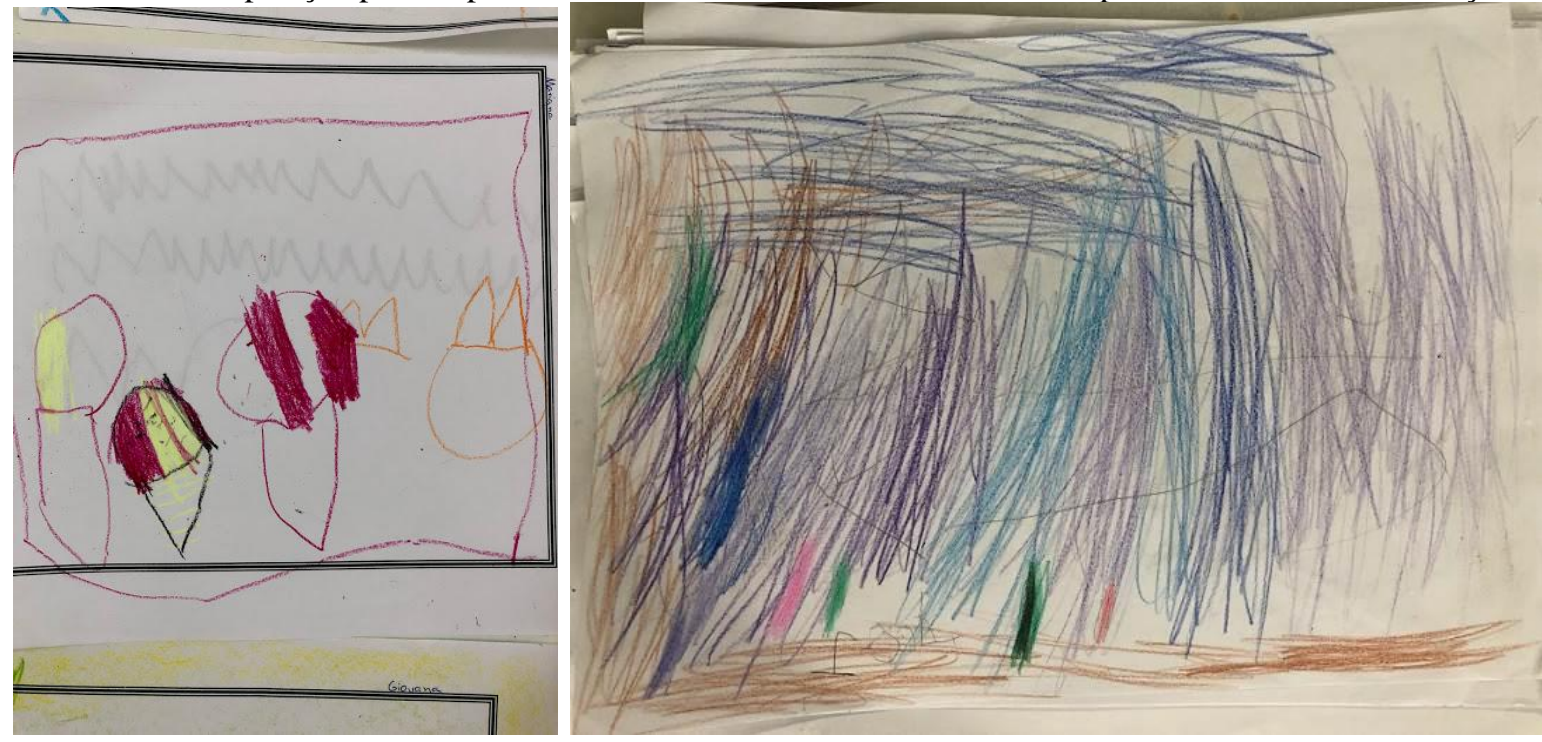

Fonte: Dos autores (2019).

Como problematiza Kohan (2005, p. 116), "Não nos preocuparemos com o que a infância pode ser, mas com o que ela é. Asseveraremos a infância como símbolo de afirmação, figura do novo, espaço de liberdade". Tomar a infância como afirmação é condição para ampliar sentidos de práticas curriculares e avaliativas que dialoguem com ela. Para Deleuze (2009, p. 45), “[...] o sentido é sempre um efeito. Não somente efeito no sentido casual; mas um efeito no sentido de efeito óptico, efeito sonoro, ou melhor, efeito de superfície, efeito de posição, efeito de linguagem". Na relação com as redes de produção de sentido, tomamos o sentido em seu aspecto disjuntivo e voltamo-nos para a distância existente entre o que se passa pelo corpo e o que se manifesta na linguagem, entre o que sentimos e o que expressamos sobre o que sentimos. Impossível traduzir em palavras o que não é vivido e sentido por nós em palavras.

- Esse é de fazer fogueira, é para acender (MENINA).

- O nome é palito de fósforo (MÃE DA MENINA).

- Essas são vermelhas, de pegar no chão (MENINA).

- Ela adora catar e colecionar sementes (MÃE DA MENINA).

- Nós fizemos um passeio muito massa para caçar as sementes que estavam no chão (PESQUISADORA).

- Esses meninos estão brincando de avião de papel (MENINA).

- Bora brincar também. Avião de papel eu sei fazer (MÃE DA MENINA).

(TRECHO DO DIÁRIO DE CAMPO, 12 de dezembro de 2018).

Essas e outras atividades ampliavam a temática e a experiência com diferentes linguagens, por meio da literatura infantil, das músicas populares, da composição de telas 
(decoradas com glíter, lantejoula, cola colorida, miçangas) e de modos de brincar, sem a pretensão de consolidar um sentido único para a experiência com a temática água. Ao final de primeiro semestre, o portifólio foi entregue às famílias e depois retomado para incluir os registros do segundo semestre. A ação de abrir e folhear suas páginas também consistia em uma oportunidade de lembrar as atividades realizadas, algumas já esquecidas.

Novamente, destacamos que esse movimento não se organizou por objetivos de aprendizagem ou campos de experiência, ${ }^{7}$ perfazendo, por exemplo, uma referência direta à BNCC. Também não podemos dizer que seguiu uma proposta definida de antemão no início do ano, ou orientada pelos documentos escolares. Como discutem Gomes et. al. (2019), embora as prescrições curriculares abordem a avaliação da aprendizagem com marcas de um processo individual e técnico, que muitas vezes conflui na descrição das crianças, outras enunciações afetivas, cognitivas, linguísticas e sociais podem contribuir para dar visibilidade aos encontros que produziram o movimento do pensamento infantil.

Em atenção a outros modos de conceber os processos de aprender, as práticas curriculares foram ampliadas em redes, assumindo sua característica de invenção de uma narrativa, cuja performance dialoga com os registros produzidos cotidianamente no encontro das professoras com as crianças.

Foto 3 - Mostra no corredor da escola

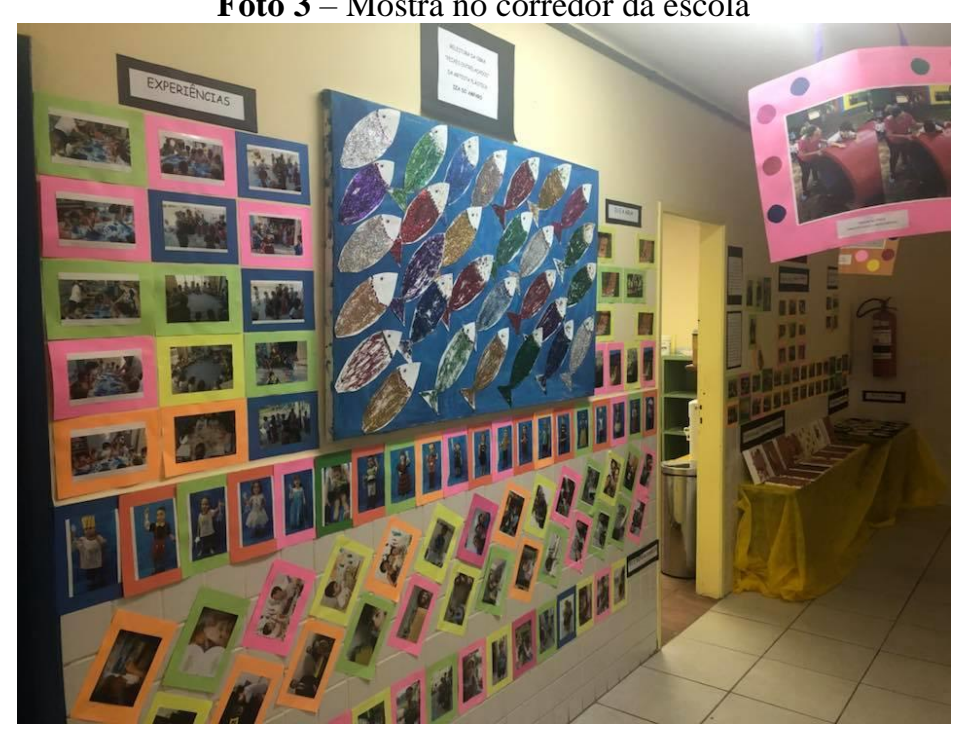

Fonte: Dos autores.

O quarto instrumento é a mostra (Foto 3), que reúne atividades realizadas pelas crianças que ampliam as experiências para além do arquivo em papel. Fotos, mandalas de argila, telas pintadas individual e coletivamente e sínteses do projeto compõem essa produção. Para sua realização, foram necessários dois dias de preparação para a impressão de fotos e seleção, organização e preparação dos demais materiais que seriam expostos. Contou com o trabalho das professora regente e auxiliar, bem como de outras duas docentes e estagiárias. 
O quinto instrumento é o vídeo, uma elaboração coletiva do tema, que não se propunha realizar uma descrição das atividades, compilação de fotos ou narrativa do vivido. Expressouse como produção cinematográfica, que buscou dar visibilidade às crianças e às diferentes experiências e linguagens potencializadas nas atividades, especialmente no pátio. Para elaborá-lo, foi necessário aprender a operar com esse recurso. A intenção era que os vídeos tivessem curta duração (até $4 \mathrm{~min}$ ), reunissem registros fílmicos das experiências infantis conforme as temáticas do projeto e garantissem a identificação de todas as crianças. Depois de uma visualização prévia, as professoras sugeriram o tema do fundo musical.

Diferente dos demais dispositivos que abordam as atividades e produções materializadas em papel, tela, argila, dentre outros, o vídeo não reúne trabalhos, mas captura as imagens das crianças, suas linguagens corporais, brincantes e interativas, suas criações, experimentações e usos dos espaços, tempos, brinquedos e sujeitos. São apresentados pequenos trechos fílmicos da vida das crianças, em um determinado contexto temático, considerando uma temporalidade específica, que afetou com outra intensidade as crianças, as professoras e as famílias.

Sem dúvida, trata-se de um expressivo recorte dos movimentos infantis coletivos na escola para guardar, rever e se emocionar. Foram apresentados na reunião com as famílias, encaminhados para que vissem com as crianças e, no retorno às aulas, elas também assistiram juntas. Uma mãe filmou o filho assistindo aos vídeos em casa. Ele narrava cada cena e se divertia se reconhecendo e aos colegas. Também assistimos, em tela grande com as crianças, aos seus filmes, às produções cinematográficas "O Grupo 3 e a água" e "O Grupo 3 e a terra", que mobilizaram outras conversas ao identificarem a si e os colegas. Os vídeos movimentavam uma história vivida mas ainda não vista, um outro recurso para fabular o que já estava no corpo, nas suas expressões, nas experimentações. ${ }^{8}$

$O$ sexto instrumento é a reunião com as famílias, que foram realizadas nas semanas que finalizavam o primeiro e o segundo semestre. Na ocasião, as professoras apresentavam uma síntese do projeto, destacando a relevância da participação das famílias sempre que foram solicitadas e pedindo a manifestação quanto ao que ressoa desse trabalho na vida das crianças.

Cabe destacar que, nesse encontro, diferente dos registros narrativos nos corredores da escola, em que as famílias cobravam a indicação de ementas ou objetivos de aprendizagem das crianças, a conversa era outra! Mostravam-se emocionadas com a leitura do portfólio, com os vídeos e com as ressonâncias da temática do projeto na vida das crianças. Uma hipótese é que buscamos trazer uma narrativa menos descritiva das crianças e mais intensiva dos encontros, o que também reverberou nas famílias.

\footnotetext{
- Agora eu entendo por que ele fica doido para brincar naquela montanha de terra todo dia na saída (MÃE).

- Eu não sabia que ele se divertia tanto rolando naquela inclinação. Entendo, agora, a roupa tão suja (MÃE).

- Mas em que tempo vocês conseguem preparar tudo para essas atividades acontecerem? São muito cuidadosas com nossos filhos (MÃE).

- O vídeo ficou profissional, parabéns pelo esforço (PAI).
} 
- Os vídeos estão uma graça, são uma lembrança linda dos colegas e do tempo em que estuda aqui (MÃE).

- Vendo tudo isso que é feito aqui, tenho mesmo que me acostumar com a ideia de que não tenho mais um bebê (MÃE).

As narrativas das famílias nos levam a compreender, como indicam Santos et al. (2015, p. 206), que, nessa instituição, “[...] não há uma prática avaliativa descontextualizada das perspectivas pedagógicas que lhes oferecem fundamento, pois não é o instrumento que determina a sua concepção, mas a intencionalidade do avaliador", nesse caso, das professoras.

Além desses elementos, as professoras dessa instituição investiram em mostras culturais, apresentação de dança, produção de livros e revistas com as crianças, dentre outros instrumentos de registro e comunicação dos processos vividos. Assim, reconhecemos que tudo isso já habita a escola. Contudo, nossa intervenção colaborativa está na concepção e na sua potência criativa para ampliar modos de pensar, fazer, registrar, reunir e compartilhar o que é feito nela.

A avaliação, como prática cartográfica de registros cotidianos, consistia em um modo de atuação imbricado com o planejamento e a atuação da professora. Na relação com as crianças, os planejamentos mensais, que discutíamos no contraturno, eram revistos, considerando, especialmente, a equipe de trabalho disponível para atender com qualidade às crianças. A intenção era garantir que, nas diferentes atividades, houvesse condições de propor desafios para o grupo (ou parte dele), ao mesmo tempo em que as crianças que não estivessem envolvidas com a proposta pudessem criar suas hipóteses em outros grupos menores ou individualmente e, assim, conseguiríamos manter a atenção para suas necessidades fisiológicas (hidratação, banho, fralda, xixi, cocô).

$\mathrm{Se}$, para as professoras, as práticas de registro contribuem para dar visibilidade às diferentes rotas dos processos vividos, para as crianças e suas famílias, os registros podem funcionar como disparadores de novas histórias do vivido. Assim, em conexão com o que é produzido na escola, vamos compreendendo que as práticas centradas no trabalho pedagógico e no desenvolvimento infantil também foram ampliadas com modos intensivos de valorizar a potência dos encontros e a fabulação de histórias de outras versões desses processos com as crianças e suas famílias.

\section{Sobre pausas nesta narrativa e questões que movem a produção coletiva}

Assumir uma concepção é se posicionar quanto à contribuição das práticas curriculares e avaliativas na escola. Com essa e outras pesquisas, ${ }^{9}$ buscamos manifestar nossa preocupação com concepções e instrumentos de avaliação discente somativos, ou seja, que valorizam os resultados com fins de medir o desempenho dos sujeitos. Os instrumentos também apontam para a valorização da meritocracia e da performatividade, com centralidade em testes de larga escala, formulários, premiações e punições. 
Em conexão com as práticas pedagógicas do cotidiano escolar, assumimos uma concepção formativa e investigativa, ou seja, que valoriza os processos aprendentes, com a finalidade de acompanhar o trabalho pedagógico e as experiências das crianças. Para tanto, os instrumentos são outros: cadernos, relatórios, portfólios, mostras, fotos, vídeos, que não se proponham apenas descrever, mas, também instaurar outras narrativas com os sujeitos. Com esse investimento, buscamos nos voltar mais para as crianças do que para os conteúdos a serem mensurados.

Além disso, neste ano de 2020, em que as escolas estão fechadas, temos buscado falar da beleza das práticas cotidianas (FERRAÇO, 2008), sem desconsiderar os sufocamentos ora provocados pelos tensionamentos políticos que dificultam o investimento na questão pública, ora pelo isolamento que enfraquece a beleza dos encontros e da vida, pela crise sanitária mundial com a pandemia do coronavírus (COVID-19). Na contramão desse movimento que nos despotencializa, comemoramos parte da aprovação do Novo Fundeb em 22 de julho de 2020 pela Câmera de Deputados, como modo de assegurar a qualidade da educação, a valorização dos profissionais da educação, a progressiva complementação da União e a previsão do Custo Aluno Qualidade (CAQ).

Contudo, reconhecemos que tratar do tema currículo e avaliação na educação infantil exige reconhecer as desigualdades estruturais do nosso país. Os direitos mais basilares ainda têm sido reivindicados pelas comunidades/movimentos sociais, a fim de reconhecerem a existência da pobreza e a manutenção dos direitos conquistados ao longo dos tempos. Como destacam Taggart et al. (2011), a pobreza, a baixa escolaridade e um ambiente familiar desestruturado interferem na interação entre os adultos e crianças no seio da família e no desenvolvimento infantil. Desse modo, políticas públicas sérias precisam considerar a permanente ampliação e manutenção dos direitos constitucionais quanto à moradia, saúde, educação e assistência.

Nosso investimento permanece em fortalecer, discutir e divulgar o que temos coletivamente produzido, seguindo critérios de qualidade contextualmente discutidos na educação infantil em atenção às crianças, tal como temos produzido em diferentes investimentos. Dentre eles, destacamos as ações colaborativas interinstitucionais, que envolvem ensino (como o estágio curricular supervisionado), pesquisas (que movem projetos individuais e coletivos de graduação e pós-graduação) e extensão universitária (cursos, seminários, oficinas) em parceria com os sujeitos das escolas e das Secretarias Municipais e Estaduais.

Também enfatizamos as reuniões, articulações e publicações que envolvem os grupos de pesquisa, associações e movimentos interfóruns, com destaque para Associação Nacional de Política e Administração da Educação (Anpae), Associação Nacional de Pós-Graduação e Pesquisa em Educação (Anped), Associação Nacional pela Formação dos Profissionais da Educação (Anfope), Associação Brasileira de Currículo (ABdC), Confederação Nacional dos Trabalhadores em Educação (CNTE), Encontro Nacional de Didática e Práticas de Ensino (Endipe), Associação Nacional de Pesquisa em Financiamento da Educação (Fineduca), Movimento Interfóruns de Educação Infantil (Mieib), União Nacional dos Dirigentes Municipais de Educação (Undime) e Campanha Nacional pelo Direito a Educação. 
Consideramos que nos interessa compor esse debate, atentos aos processos infantis e aos diferentes modos de registro, em conexão com as prescrições curriculares, as políticas públicas e as práticas pedagógicas que investem nessa coletividade, e que buscam a qualidade da educação infantil brasileira.

\section{Notas:}

1. A pesquisa foi desenvolvida por ocasião do estágio pós-doutoral, modalidade Pós-Doutorado Júnior, com concessão de bolsa pelo Programa Básico de Educação do Conselho Nacional de Desenvolvimento Científico e Tecnológico (CNPq).

2. O Conselho Nacional de Educação foi criado em 1996, em substituição ao Conselho Federal de Educação. Uma parte dos novos membros é indicada por um conjunto representativo de entidades (BRASIL; PQNEI, 2006).

3. O primeiro Plano Nacional de Educação foi aprovado pela Lei $\mathrm{n}^{\circ} 10.172$, de 9 de janeiro de 2001, para o período de 2001 a 2011. Após interstício de três anos, o segundo Plano Nacional de Educação foi aprovado pela Lei $\mathrm{n}^{\circ}$ 13.005, de 25 de junho de 2014, para o período entre 2014 e 2024.

4. A respeito de propostas de avaliação de larga escala nas redes estaduais, Bauer e Horta Neto (2018, p. 18 19) mapearam estudos recentes e indicam que, dos 27 estados brasileiros, 20 possuem suas próprias propostas. São eles "Acre - Sistema Estadual de Avaliação da Aprendizagem Escolar (Seape); Alagoas Sistema de Avaliação Educacional de Alagoas (Saveal); Amazonas - Sistema de Avaliação do Desempenho Educacional do Amazonas (Sadeam); Bahia - Sistema de Avaliação Baiano de Educação (Sabe); Ceará Sistema Permanente de Avaliação da Educação Básica do Ceará (Spaece); Distrito Federal - Sistema de Avaliação de Desempenho das Instituições Educacionais do Distrito Federal (Siade); Espírito Santo Programa de Avaliação da Educação Básica do Espírito Santo (Paebes); Goiás - Sistema de Avaliação Educacional do Estado de Goiás (Saego); Minas Gerais - Sistema Mineiro de Avaliação da Educação Pública (Simave); Mato Grosso do Sul - Sistema de Avaliação da Rede Pública de Mato Grosso do Sul (Saems); Pará - Sistema Paraense de Avaliação Educacional (Sispae); Paraíba - Sistema de Avaliação da Educação da Paraíba (Avaliando Idepb); Paraná - Sistema de Avaliação da Educação Básica do Paraná (Saep); Pernambuco - Sistema de Avaliação Educacional de Pernambuco (Saepe); Piauí - Sistema de Avaliação Educacional do Piauí (Saepi); Rio de Janeiro - Sistema de Avaliação da Educação do Estado do Rio de Janeiro (Saerj); Rio Grande do Sul - Sistema Estadual de Avaliação Participativa (Seap); Rondônia - Sistema de Avaliação Educacional de Rondônia (Saero); São Paulo - Sistema de Avaliação do Rendimento Escolar do Estado de São Paulo (Saresp); Tocantins - Sistema de Avaliação da Educação do Tocantins (Salto)".

5. Santos, Paula e Stieg (2019, p. 100) indicam a criação de políticas educacionais e sistemas internacionais de avaliação que, em geral, realizam estudos comparativos em larga escala, criam dispositivos para mensurar os resultados, bem como analisar a realidade e as dificuldades educacionais, tais como: "[...] International Association for the Evaluation of Educational Achievement (IEA), Programa de Promoção das Reformas Educacionais na América Latina e Caribe (PREAL), Organización para La Cooperación y El Desarrollo Económicos (OCDE) e Programme for International Student Assessment (Pisa)".

6. O Governo Federal publicou, no Diário Oficial da União do dia 10 de janeiro, o Decreto $n^{\circ}$ 9.262/18, que extingue, ao todo, 60.923 cargos da administração pública federal e impede novas nomeações de concursos já realizados. Para saber mais, conferir: http://www.planalto.gov.br/ccivil_03/_ato20152018/2018/decreto/D9262.htm. Acesso em: 15 fev. 2019.

7. A BNCC (2019) identifica os cinco campos de experiências e seus objetivos, considerando a especificidade de bebês, crianças bem pequenas e crianças pequenas: "O eu, o outro, o nós", "Corpo, gesto e movimentos", "Traços, sons, cores e formas", "Escuta, fala, pensamento e imaginação", "Espaços, tempos, quantidades, relações e transformações". 
8. Outros trabalhos nessa instituição têm investido nas conexões com vídeos e cinema. Para saber mais, ver Zouain (2019) e Zouain e Gomes (2019).

9. Para saber mais, ver as produções dos grupos de pesquisa do CNPq “Currículos, cotidianos, culturas e redes de conhecimentos" e "Currículos, culturas juvenis e produção de subjetividades" que compõe o Núcleo de Pesquisa e Extensão em Currículos, Culturas e Cotidianos (Nupec3/CE-Ufes). Disponível em: https://nupec.ufes.br/. Também as produções do Grupo de Pesquisa em Educação Física Escolar (GPEF/FEUSP). Disponível em: http://www.gpef.fe.usp.br/.

\section{Referências}

AGUIAR, M. Â. S. Relato da resistência à instituição da BNCC pelo Conselho Nacional de Educação mediante pedido de vista e declarações de votos. In: AGUIAR, M.; DOURADO, L. F. (org.). A BNCC na contramão do PNE 2014-2024: avaliação e perspectivas. Recife: ANPAE, 2018. p. 8-22.

ALVES, N. Decifrando o pergaminho: os cotidianos das escolas nas lógicas das redes cotidianas. ALVES, N.; OLIVEIRA, I. B. (org.). Pesquisa nos/dos/com os cotidianos das escolas: sobre redes de saberes. Petrópolis: DP et Alii, 2008.

ASSIS, L. M.; AMARAL, N. C. Avaliação da educação: por um sistema nacional. Retratos da Escola, v. 7, n. 12, p. 65-75, jan./jun. 2013. (Dossiê Avaliação da Educação Básica).

BAUER, A.; HORTA NETO, J. L. Avaliação e gestão educacional em municípios brasileiros: mapeamento e caracterização de iniciativas em curso. Relatório final: resultados do survey. Brasília: Instituto Nacional de Estudos e Pesquisas Educacionais Anísio Teixeira, 2018. v. 1.

BHERING, E.; ABUCHAIM, B. O. Monitoramento da educação infantil pública: possibilidades e conteúdos. Estudos em Avaliação Educacional, São Paulo, v. 25, n. 58, p. 74-99, maio/ago. 2014

BRASIL. Ministério da Educação. Base Nacional Comum Curricular. Brasília, DF: MEC, 2018.

Emenda Constitucional $n^{\circ}$ 59/09. Diário Oficial da União da República Federativa do Brasil, Brasília, DF, 11 nov. 2009c.

Lei $\mathrm{n}^{\circ}$ 8.069, de 13 de julho de 1990. Dispõe sobre o Estatuto da Criança e do Adolescente e dá outras providências. Diário Oficial da União da República Federativa do Brasil, Brasília, DF, 16 jul. 1990.

Lei $n^{\circ}$ 9.394, de 20 de dezembro de1996. Estabelece as diretrizes e bases da educação nacional. Diário Oficial da União da República Federativa do Brasil, Brasília, DF, 23 dez. 1996.

Lei no 13.005, de 25 de junho de 2014. Aprova o Plano Nacional de Educação (PNE) e dá outras providências. Diário Oficial da União da República Federativa do Brasil, Brasília, DF, 26 jun. 2014.

. Ministério da Educação. Secretaria de Educação Básica. Diretrizes curriculares nacionais para a educação infantil/ Secretaria de Educação Básica. Brasília: MEC, SEB, 2010. Disponível em: http://ndi.ufsc.br/files/2012/02/Diretrizes-Curriculares-para-a-E-I.pdf. Acesso em: 10 jan. 2019.

CARVALHO, M. A. S.; COSTA, S. S. Avaliação na educação infantil: tendências e desafios. Revista Retratos da Escola, Brasília, v. 7, n. 12, p. 179-190, jan./jun. 2013.

CIASCA, M. I. F. L.; MENDES, D. L. L. L. Estudos em Avaliação Educacional, São Paulo, v. 20, n. 43, p. 293-304, maio/ago. 2009.

CURY, C. R. J.; REIS M.; ZANARDI, T. A. C. Base Nacional Comum Curricular: dilemas e perspectivas. São Paulo: Cortez, 2018.

DELEUZE, G. Lógica do sentido. São Paulo: Perspectiva, 2009.

DELEUZE, G.; GUATTARI, F. Mil platôs: capitalismo e esquizofrenia. Tradução de Aurélio Guerra Neto e Célia Pinto Costa. Rio de Janeiro: Ed. 34, 1996. v. 3. 
DIDONET, V. A avaliação na e da educação infantil. Brasília, jun. 2012.

FERRAÇO, C. E. A pesquisa em educação no/do/com o cotidiano das escolas. In: FERRAÇO, C. E.; PEREZ, C. L. V.; OLIVEIRA, I. B. (org.). Aprendizagens cotidianas com a pesquisa: novas reflexões em pesquisa nos/dos/com os cotidianos. Petrópolis: DP et Alii, 2008. p. 23-34.

FRANCELINO, K. S.; FERNANDES, S. R.; JUSTINO, M. G. Contribuições das assistentes de educação infantil: compondo currículos e avaliações. In: ENCONTRO NACIONAL DE DIDÁTICA E PRÁTICA DE ENSINO: Para onde vai a didática? O enfrentamento às abordagens teóricas e desafios políticos da atualidade. 19., UFBA, Anais [...]. Bahia, 2018.

GOMES, L. F. R.; ZOUAIN, A. C. S.; NUNES, K. R. Se não se sabe de antemão como alguém vai aprender, como avaliar na educação infantil? Revista Espaço do Currículo (on-line), João Pessoa, v. 12, n. 2, p. 339-351, maio/ago. 2019.

KASTRUP, V. O funcionamento da atenção no trabalho do cartógrafo. Revista Psicologia e Sociedade, Belo Horizonte, v. 1, n. 19, p. 15-22, jan./abr. 2007.

KOHAN, W. Infância: entre educação e filosofia. Belo Horizonte: Autêntica, 2005

LOPES, A. C. Apostando na produção contextual do currículo. In: AGUIAR, M.; DOURADO, L. F. (org.). A BNCC na contramão do PNE 2014-2024: avaliação e perspectivas. Recife: ANPAE, 2018. p. 23-27. 2013.

MORO, C.; SOUZA, G. Produção acadêmica brasileira sobre avaliação em educação infantil: primeiras aproximações. Estudos em Avaliação Educacional, São Paulo, v. 25, n. 58, p. 100-125, maio/ago. 2014.

MULlER, A.; NEIRA, M. G. Avaliação e registro no currículo cultural da educação física. Estudos em Avaliação Educacional., São Paulo, v. 29, n. 72, p. 774-800, set./dez. 2018.

NUNES, K. R. Currículos com crianças em creches: potencializando linguagens e ampliando sentidos de avaliação. 2019. Relatório (Pós-Doutorado em Educação) - Universidade de São Paulo, São Paulo, 2019.

NUNES, K. R.; RIBEIRO, M. R. M.; ROCHA, T. B. Avaliação na educação infantil: produzindo sentidos nas relações com os bebês no cotidiano escolar. In: SEMINÁRIO INTERNACIONAL AS REDES EDUCATIVAS E AS TECNOLOGIAS: educação e democracia, aprenderensinar para um mundo plural e igualitário, 9., 2017, Rio de Janeiro. Anais [...]. Rio de Janeiro, 2017.

RIBEIRO, M. N.; NUNES, K. R.; RANGEL, I. S. Currículo e avaliação: sentidos produzidos entre o espaço doméstico e o educacional. In: ENCONTRO NACIONAL DE DIDÁTICA E PRÁTICA DE ENSINO: Para onde vai a didática? O enfrentamento às abordagens teóricas e desafios políticos da atualidade. 19., UFBA, Anais [...]. Bahia, 2018.

ROSEMBERG, F. Políticas de educação infantil e avaliação. Cadernos de Pesquisa, São Paulo, v. 43, n. 148, p. 44-75, jan./abr. 2013.

SACRISTÁN, J. G. O currículo: uma reflexão sobre a prática. Porto Alegre: Artmed, 2000.

SOUSA, S. M. Z. L. Avaliação da educação infantil: questões controversas e suas implicações educacionais e sociais. Revista Educação PUC-Camp., Campinas, v. 23, n. 1, 2018.

SANTOS, W.; PAULA, S.; STIEG, R. Avaliações institucionais e de sistemas na formação de professores em educação física na América Latina. Revista Espaço Pedagógico, Passo Fundo, v. 26, n. 1, p. 99-116, jan./abr. 2019.

SILVA, T. T. Documentos de identidade: uma introdução às teorias do currículo. Belo Horizonte: Autêntica, 1999.

SUBTIL, R. S. F.; GOMES, L. F. R. Perspectivas cotidianas de docência na educação infantil: movimentos avaliativos. In: ENCONTRO NACIONAL DE DIDÁTICA E PRÁTICA DE ENSINO: Para onde vai a 
didática? O enfrentamento às abordagens teóricas e desafios políticos da atualidade. 19., UFBA, Anais [...]. Bahia, 2018.

TAGGART, B.; SYLVA, K; MELHUISH, E.; SAMMONS, P.; J-BLA TCHFORD, I. O poder da pré-escola: evidências de um estudo longitudinal na Inglaterra. Cadernos de Pesquisa, v. 41, n. 142, jan./abr. 2011.

VIEIRA, A. O. Por uma teorização da avaliação em educação física: práticas de leituras por narrativas imagéticas. 2018. Tese. (Doutorado em Educação Física) - Universidade Federal do Espírito Santo, Vitória, 2018.

ZOUAIN, A. C. Crianças cineastas e seus roteiros criarteiros: infâncias, currículos e roteiros inventivos. 2019. Dissertação. (Mestrado Profissional em Educação) - Universidade Federal do Espírito Santo, Vitória, 2019.

ZOUAIN, A. C.; GOMES, L. F. R. Crianças e professores cineastas na educação infantil. Documentário. 2019. Disponível em: https://www.youtube.com/watch?v=xYyPZC5DK8s. Acesso em: 30 abr. 2020.

\section{Correspondência}

Kezia Rodrigues Nunes: É licenciada em Educação Física (Ufes, 2003), com Especialização em Educação Física para Educação Básica (Ufes, 2005), Mestrado em Educação Física (Ufes, 2007), Doutorado em Educação (Ufes, 2012) e Pós-Doutorado em Educação (USP, 2019). Atua como professora do Centro de Educação da Ufes, nos cursos de licenciatura em Educação Física e em Pedagogia. Tem experiência na Educação Básica, no Ensino Superior, na Formação Continuada de Professores/as e em pesquisa com os seguintes temas: Educação Infantil, Educação Física escolar, Currículo, Cotidiano, Avaliação e Estágio Supervisionado. É Co-coordenadora do Núcleo de Pesquisa e Extensão em Currículo, Cultura e Cotidiano (NUPEC3, UFES).

E-mail: keziarnunes@gmail.com

Marcos Garcia Neira: É licenciado em Educação Física e em Pedagogia, com Mestrado e Doutorado em Educação, Pós-doutorado em Currículo e Educação Física e Livre-Docência em Metodologia do Ensino de Educação Física. Atua como professor Titular da Faculdade de Educação da Universidade de São Paulo, onde exerce a função de Diretor (2018-2022) e atua nos cursos de graduação e pós-graduação. Investiga a prática pedagógica da Educação Física com apoio da FAPESP e do CNPq, do qual é Bolsista de Produtividade em Pesquisa. Tem experiência com os seguintes temas: Educação Física escolar, Currículo, Formação de professores e Teorias pós-críticas. Coordenador do Grupo de Pesquisas em Educação Física Escolar da Faculdade de Educação da Universidade de São Paulo (GPEF, FEUSP).

E-mail: $\underline{\text { mgneira@usp.br }}$

Texto publicado em Currículo sem Fronteiras com autorização dos autores. 